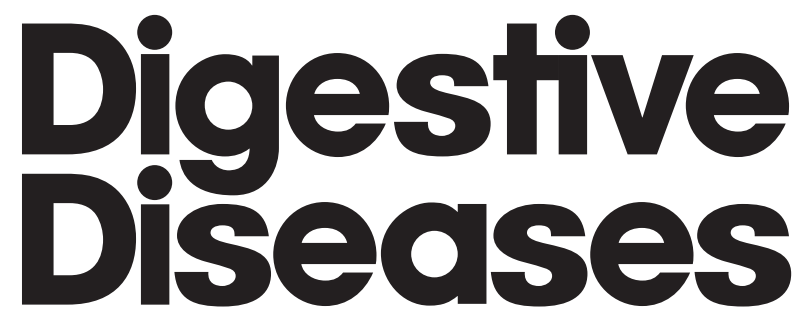

The Latest in Diagnosis and Treatment of

\title{
Gastrointestinal Disorders
}

Formerly "Survey of Digestive Diseases"

Founded in 1983 by T.S.N. Chen and R.K. Zetterman

Former Editor: S.R. Achem (1993-2000)

\section{Editor-in-Chief}

Peter Malfertheiner - University Hospital Magdeburg, Magdeburg, Germany

\section{Managing Editors}

Jan Bornschein - Oxford University Hospitals, Headington, United Kingdom

Luigi Ricciardiello - University of Bologna, Bologna, Italy

\section{Associate Editors}

\section{Official Journal of}

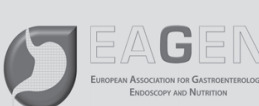

European Association for Gastroenterology and Endoscopy

\section{EAGEN Society Representatives}

L. Lundell, Stockholm

J. Regula, Warsaw

J. Tack, Leuven

\section{Affiliated with}

Healthy Stomach Initiative

\section{Esophagus}

Lawrence Khek Yu Ho - National University Singapore, Singapore

Magnus Nilsson - Karolinska Institute, Stockholm, Sweden

\section{Stomach and Duodenum}

Franco Bazzoli - Università di Bologna, Bologna, Italy

Kentaro Sugano - Jichi Medical University, Shimotsuke, Japan

Small and Large Bowel

Jaroslaw Regula - The Maria Sklodowska-Curie Memorial Cancer Center and Institute of Oncology, Warsaw, Poland

Gerhard Rogler - University Hospital Zurich, Zurich, Switzerland

Liver

Ali E. Canbay - Universitätsklinikum Magdeburg A.ö.R, Magdeburg, Germany

Valerio Nobili - Bambino Gesu Children Hospital, Rome, Italy 


\section{Digestive Diseases}

\section{Pancreas}

Marco J. Bruno - Erasmus MC University Medical Center, Rotterdam, The Netherlands

Christiane J. Bruns - University Hospital Cologne, Cologne, Germany

Julia Mayerle - Ludwig-Maximilians-University, Munich, Germany

\section{Microbiota}

Antonio Gasbarrini - "Agostino Gemelli" University Hospital, Rome, Italy Mirjana Rajilić-Stojanović - University of Belgrade, Belgrade, Serbia

Endoscopy and Imaging

Yoji Takeuchi - Osaka Medical Center for Cancer and Cardiovascular Disease, Osaka, Japan

Jochen Weigt - Otto-v.-Guericke University, Magdeburg, Germany

Nutrition and Probiotics

Uday C. Ghoshal - Sanjay Gandhi Post Graduate Institute of Medical Sciences, Lucknow, India

\section{Editorial Board}

Tiing Leon Ang - Changi General Hospital Singapore, Singapore Marco Del Chiaro - Karolinska Institutet at Center for Digestive Diseases, Stockholm, Sweden

Leonardo H. Eusebi - University of Bologna, Bologna, Italy

Matteo Fassan - University of Padua, Padua, Italy

Pradermchai Kongkam - Chulalongkorn University, Bangkok, Thailand Michael Scharl - University Hospital Zurich, Zurich, Switzerland Michael Quante - Klinikum rechts der Isar, Munich, Germany

Abhai Verma - Sanjay Gandhi Post Graduate Institute of Medical Sciences, Lucknow, India

Rocco Maurizio Zagari - University of Bologna, Bologna, Italy

\section{KARGER}

(C) 2017 S. Karger AG, Basel 
S. Karger

Medical and Scientific Publishers Basel $\bullet$ Freiburg $\bullet$ Paris $\bullet$ London

New York $\cdot$ Chennai $\cdot$ New Delhi $•$

Bangkok $\cdot$ Beijing $\cdot$ Shanghai $\cdot$ Tokyo •

Kuala Lumpur $\cdot$ Singapore $\cdot$ Sydney
Disclaimer

The statements, opinions and data contained in this publication are solely those of the individual authors and contributors and not of the publisher and the editor(s). The appearance of advertisements in the journal is not a warranty, endorsement, or approval of the products or services advertised or of their effectiveness, quality or safety. The publisher and the editor(s) disclaim responsibility for any injury to persons or property resulting from any ideas, methods, instructions or product referred to in the content or advertisements.

Drug Dosage

The authors and the publisher have exerted every effort to ensure that drug selection and dosage set forth in this text are in accord with current recommendations and practice at the time of publication. However, in view of ongoing research, changes in government regulations, and the constant flow of information relating to drug therapy and drug reactions, the reader is urged to check the package insert for each drug for any change in indications and dosage and for added warnings and precautions. This is particularly important when the recommended agent is a new and/or infrequently employed drug.
All rights reserved.

No part of this publication may be translated into other languages, reproduced or utilized in any form or by any means, electronic or mechanical, including photocopying, recording, microcopying, or by any information storage and retrieval system, without permission in writing from the publisher or in the case of photocopying, direct payment of a specified fee to the Copyright Clearance Center (see 'General Information').

(c) Copyright 2017 by S. Karger AG

CH-4009 Basel (Switzerland)

Printed on acid-free and non-aging paper (ISO 9706) 
No. 1-2

Evolving Therapies in Clinical Practice in IBD

Editors: Lukas, M. (Prague); Bortlik, M. (Prague); Kruis, W. (Cologne); Stange, E.F. (Stuttgart)

Novel Therapeutic Approaches in Medical Therapy

5 Anti-Cytokine Strategies beyond Anti-Tumour Necrosis Factor-a Therapy: Pathophysiology and Clinical Implications Rogler, G.; Biedermann, L.; Scharl, M. (Zurich)

13 Leukocyte Anti-Trafficking Strategies: Current Status and Future Directions Sands, B.E. (New York, N.Y.)

21 Improvement of a 'Leaky' Intestinal Barrier Stange, E.F. (Stuttgart)

Unmet Therapeutic Needs: Focus on Intestinal Fibrosis

25 Pathogenesis of Intestinal Fibrosis in Inflammatory Bowel Disease and Perspectives for Therapeutic Implication Bettenworth, D. (Münster); Rieder, F. (Cleveland, Ohio)

32 Measurement of Fibrosis in Crohn's Disease Strictures with Imaging and Blood Biomarkers to Inform Clinical Decisions Higgins, P.D.R. (Ann Arbor, Mich.)

38 Unmet Therapeutic Needs: Focus on Intestinal Fibrosis Surgical Approach: Resection, Strictureplasty and Others Mege, D.; Panis, Y. (Clichy)

How to Improve Our Care in IBD?

45 Late-Onset of Acute Severe Ulcerative Colitis: Clinical Case Dorofeyev, A.E.; Rassokhina, O.A.; Dorofeyeva, A.A. (Kiev)

50 What Should Be Done in Inflammatory Bowel Disease Patients with Prior Malignancy?

Cosnes, J. (Paris)

How to Best Use the Drugs?

56 Promises and Dangers of Combination Therapy Kruis, W.; Nguyen, P.G.; Morgenstern, J. (Cologne)

61 Combining Therapeutic Drug Monitoring with Biosimilars, a Strategy to Improve the Efficacy of Biologicals for Treating Inflammatory Bowel Diseases at an Affordable Cost

Gils, A. (Leuven)

Special Lecture

69 What Can We Learn from Epidemiological Studies in Inflammatory Bowel Disease?

Duricova, D. (Prague)
Biosimilars in Clinical Practice

74 Does the Introduction of Biosimilars Change Our Understanding about Treatment Modalities for Inflammatory Bowel Disease?

Buer, L.; Høivik, M.L.; Medhus, A.W.; Moum, B. (Oslo)

Focus on European Experience

83 Experience with Biosimilar Infliximab (Remsima ${ }^{\circledR}$ ) in Norway Jahnsen, J. (Lørenskog/Oslo); Kaasen Jørgensen, K. (Lørenskog)

91 Infliximab Biosimilar (Remsima ${ }^{\mathrm{TM}}$ ) in Therapy of Inflammatory Bowel Diseases Patients: Experience from One Tertiary Inflammatory Bowel Diseases Centre

Kolar, M.; Duricova, D.; Bortlik, M.; Hruba, V.; Machkova, N.; Mitrova, K.; Malickova, K.; Lukas Jr., M.; Lukas, M. (Prague)

101 Real-Life Efficacy, Immunogenicity and Safety of Biosimilar Infliximab

Vegh, Z.; Kurti, Z.; Lakatos, P.L. (Budapest)

Transplantation Procedures in the Therapy of IBD

107 Hematopoietic Stem Cell Transplantation in Crohn's Disease: State-of-the-Art Treatment Hawkey, C.J. (Nottingham)

115 Mesenchymal Stromal Cell Therapy in Crohn's Disease Forbes, G.M. (Perth)

123 Fecal Microbiota Transplantation in Inflammatory Bowel Disease Reinisch, W. (Hamilton)

127 Crohn's Disease and Intestinal Transplantation Drastich, P.; Oliverius, M. (Prague)

Challenging Clinical Cases

134 Case Report: Acute Flair of Ulcerative Colitis during Pregnancy Is Still a Major Problem

Protic, M.; Markovic, S.; Tarabar, D. (Belgrade)

Special Lecture

139 Intestinal Microbiota: Facts and Fiction

Kverka, M.; Tlaskalová-Hogenová, H. (Prague)

148 Falk Symposium Series

151 Author Index

152 Subject Index

\section{KARGER}

E-Mail karger@karger.com www.karger.com (c) 2017 S. Karger AG, Basel

Access to full text and tables of contents, including tentative ones for forthcoming issues: www.karger.com/ddi_issues 
No. 3

XXIV International Bile Acid Meeting: Bile Acids in Health and Disease

Editors: Häussinger, D. (Düsseldorf); Beuers, U. (Amsterdam); Keitel, V. (Düsseldorf); Trauner, M. (Vienna)

157 Preface

Häussinger, D. (Düsseldorf)

Bile Acid Signaling in Liver Regeneration and Tumor Development

158 Fibroblast Growth Factor 15/19 in Hepatocarcinogenesis Alvarez-Sola, G.; Uriarte, I.; Latasa, M.U.; Urtasun, R.; Bárcena-Varela, M.; Elizalde, M.; Jiménez, M.; Rodriguez-Ortigosa, C.M.; Corrales, F.J.;

Fernández-Barrena, M.G.; Berasain, C.; Avila, M.A. (Pamplona)

Bile Acids and the Gut Liver Axis

166 Role of the Intestinal Microbiome in Cholestatic Liver Disease LaRusso, N.F.; Tabibian, J.H.; O’Hara, S.P. (Rochester, Minn.)

169 Disease-Associated Changes in Bile Acid Profiles and Links to Altered Gut Microbiota

Joyce, S.A.; Gahan, C.G.M. (Cork)

178 Intestinal Farnesoid X Receptor Signaling Modulates Metabolic Disease

Gonzalez, F.J. (Bethesda, Md.); Jiang, C. (Beijing); Xie, C. (Bethesda, Md.); Patterson, A.D. (University Park, Pa.)

185 Farnesoid X Receptor an Emerging Target to Combat Obesity De Magalhaes Filho, C.D.; Downes, M.; Evans, R.M. (La Jolla, Calif.)

191 Impact of Fibroblast Growth Factors 19 and 21 in Bariatric Metabolism

Patton, A. (Athens, Ohio); Khan, F.H. (Cincinnati, Ohio); Kohli, R. (Los Angeles, Calif.)

Adolf Windaus Award Lecture

197 Progress in the Molecular Characterization of Hepatobiliary Transporters

Keppler, D. (Heidelberg)

Intrahepatic Signaling and Bile Acids as Endogenous Toxins

203 Regulation of Liver Energy Balance by the Nuclear Receptors Farnesoid X Receptor and Peroxisome Proliferator Activated Receptor a

Kim, K.H.; Moore, D.D. (Houston, TX)

210 Bile Acids and Deregulated Cholangiocyte Autophagy in Primary Biliary Cholangitis

Sasaki, M. (Kanazawa); Nakanuma, Y. (Kanazawa/Shizuoka)

217 The Emerging Role of Soluble Adenylyl Cyclase in Primary Biliary Cholangitis

Chang, J.-C.; Beuers, U.; Oude Elferink, R.P.J. (Amsterdam)

224 Mechanisms of Tauroursodeoxycholate-Mediated Hepatoprotection

Häussinger, D.; Kordes, C. (Düsseldorf)

232 The Role of Inflammation in the Mechanisms of Bile Acid-Induced Liver Damage

Cai, S.-Y.; Boyer, J.L. (New Haven, Conn.)

235 Role of the G Protein-Coupled Bile Acid Receptor TGR5 in Liver Damage

Reich, M.; Klindt, C.; Deutschmann, K.; Spomer, L.; Häussinger, D.; Keitel, V. (Düsseldorf)

241 Intestinal Farnesoid X Receptor and Takeda G Protein Couple Receptor 5 Signaling in Metabolic Regulation

Chiang, J.Y.L.; Pathak, P.; Liu, H.; Donepudi, A.; Ferrell, J.; Boehme, S.; (Rootstown, Ohio)
246 Crosstalk between Bile Acids and Gut Microbiota and Its Impact on Farnesoid X Receptor Signalling

Wahlström, A.; Kovatcheva-Datchary, P.; Ståhlman, M. (Gothenburg); Bäckhed, F.; (Gothenburg/Copenhagen); Marschall, H.-U. (Gothenburg)

Bile Acid Transporters: Role in Health and Disease

251 Bile Acid Uptake Transporters as Targets for Therapy Slijepcevic, D.; van de Graaf, S.F.J. (Amsterdam)

259 Extended Abstract: Deficiency of Sodium Taurocholate Cotransporting Polypeptide (SLC10A1): A New Inborn Error of Metabolism with an Attenuated Phenotype

Vaz, F.M. (Amsterdam); Huidekoper, H.H. (Rotterdam); Paulusma, C.C. (Amsterdam)

261 Roles of Ileal ASBT and OSTa-OST $\beta$ in Regulating Bile Acid Signaling

Dawson, P.A. (Atlanta, Ga.)

267 Apical Sodium-Dependent Transporter Inhibitors in Primary Biliary Cholangitis and Primary Sclerosing Cholangitis Hegade, V.S.; Jones, D.E.J. (Newcastle upon Tyne); Hirschfield, G.M. (Birmingham)

Bile Acid Receptors and Bile Acid Signaling as Therapeutic Targets

275 Bile Acids in Polycystic Liver Diseases: Triggers of Disease Progression and Potential Solution for Treatment

Perugorria, M.J. (San Sebastián/Madrid/Bilbao); Labiano, I. (San Sebastián/ Madrid); Esparza-Baquer, A. (San Sebastián); Marzioni, M. (Ancona); Marin, J.J.G. (Madrid/Salamanca); Bujanda, L. (San Sebastián/Madrid); Banales, J.M. (San Sebastián/Madrid/Bilbao)

282 Therapeutic Mechanisms of Bile Acids and Nor-Ursodeoxycholic Acid in Non-Alcoholic Fatty Liver Disease

Steinacher, D.; Claudel, T.; Trauner, M. (Vienna)

288 Nor-Ursodeoxycholic Acid as a Novel Therapeutic Approach for Cholestatic and Metabolic Liver Diseases Halilbasic, E.; Steinacher, D.; Trauner, M. (Vienna)

293 Falk Symposium Series

296 Author Index

297 Subject Index

No. 4

Clinical Hepatology Practice in 2016: From Science to Therapy Editors: Hirschfield, G.; Adams, D.H. (Birmingham); Thimme, R. (Freiburg)

303 Preface

Hirschfield, G. (Birmingham)

Hepatology 2016 - The Panorama

304 Lessons from Epidemiology: The Burden of Liver Disease Rowe, I.A. (Leeds)

310 Liver Fibrosis: Understanding the Dynamics of Bidirectional Wound Repair to Inform the Design of Markers and Therapies Iredale, J.P. (Bristol); Pellicoro, A.; Fallowfield, J.A. (Edinburgh)

314 Current and Future Magnetic Resonance Technologies for Assessing Liver Disease in Clinical and Experimental Medicine Bawden, S.J.; Scott, R.A.; Aithal, G.P. (Nottingham)

323 Genetic Discoveries Highlight Environmental Factors as Key Drivers of Liver Disease

Chung, B.K. (Birmingham/Oslo); Karlsen, T.H. (Oslo) 
The Science of Hepatitis

334 Overcoming CD8+ T-Cell Exhaustion in Viral Hepatitis: Lessons from the Mouse Model and Clinical Perspectives

Wieland, D.; Hofmann, M.; Thimme, R. (Freiburg)

Hepatitis Treatment: The Challenges

339 Treating Hepatitis C in Patients with Renal Failure Lens, S.; Rodriguez-Tajes, S.; Llovet, L.-P.; Maduell, F.; Londoño, M.-C. (Barcelona)

347 Pre- and Post-Transplant Treatment of Viral Hepatitis C Mutimer, D. (Birmingham)

351 Hepatitis B Reactivation: The Controversies Continue Feld, J.J. (Toronto, ON)

Autoimmune Liver Disease

359 What Comes after Ursodeoxycholic Acid in Primary Biliary Cholangitis?

Wong, L.L.; Hegade, V.S.; Jones, D.E.J. (Newcastle upon Tyne)

367 Can Understanding the Pathogenesis of Autoimmune Hepatitis Lead to Rational Therapy?

Lohse, A.W.; Herkel, J.; Weiler-Normann, C. (Hamburg)

Metabolic Liver Disease

371 The Role of a Dedicated Non-Alcoholic Fatty Liver Disease Clinic in 2016

Townsend, S.A.; Newsome, P.N. (Birmingham)

377 The Gut Microbiota and the Hepatologist: Will Our Bugs Prove to be the Missing Link?

Pallen, M.J. (Coventry); Quraishi, M.N. (Birmingham)

Liver and Bile Duct Cancer

384 Treating Hepatobiliary Cancers: The Oncology Way Galle, P.R. (Mainz)

387 Stemness in Liver Cancer Thorgeirsson, S.S. (Bethesda, MD)

390 Treating Hepatobiliary Cancer: The Immunologic Approach Duffy, A.G.; Greten, T.F. (Bethesda, MD)

\section{Complications of Liver Disease}

397 Novel Approaches to Reducing the Risk of Variceal

Hemorrhage

Nevens, F. (Leuven)

402 Translating Our Current Understanding of Ascites Management into New Therapies for Patients with Cirrhosis and Fluid Retention

Pose, E.; Cardenas, A. (Barcelona)

411 Nutrition and Liver Health

Jackson, A.A. (Southampton)

418 Falk Symposium Series

421 Author Index

422 Subject Index
No. 5

Original Papers

423 Long-Term Efficacy and Safety of Certolizumab Pegol in an Unselected Crohn's Disease Population: The FACTS III Survey Vavricka, S.R.; Spasojevic, M.; Rogler, G. (Zurich); Schoepfer, A.M. (Lausanne); Seibold, F. (Bern); Borovicka, J. (St. Gallen); Frei, P.; Zeitz, J.; Greuter, T. (Zurich); Manser, C. (Olten); Scharl, M.; Misselwitz, B. (Zurich); Straumann, A. (Olten); Michetti, P. (Lausanne); Biedermann, L. (Zurich) for the SWiss IBDNet

433 Hospitalizations Due to Cirrhosis: Clinical Aspects in a Large Cohort of Italian Patients and Cost Analysis Report

Di Pascoli, M.; Ceranto, E.; De Nardi, P.; Donato, D.; Gatta, A.; Angeli, P.; Pontisso, P. (Padua)

439 Inhibition of Ceramide Decreased the Expression of ATPBinding Cassette Transporter G5/8 mRNA in an Animal Model of Cholesterol Gallstone

Kim, H.J.; Kim, J.S.; Oh, S. (Seoul); Yoo, H.-S. (Cheongju)

444 Intravenous Iron Replacement Improves Quality of Life in Hypoferritinemic Inflammatory Bowel Disease Patients with and without Anemia

Eliadou, E.; Kini, G.; Huang, J.; Champion, A. (Lower Hutt); Inns, S.J. (Lower Hutt/Wellington)

449 Benign Exocrine Pancreatic Diseases in Inflammatory Bowel Diseases

Pezzilli, R.; Pagano, N. (Bologna)

454 Shared Decision Making and Treatment Satisfaction in Japanese Patients with Inflammatory Bowel Disease Mahlich, J. (Tokyo/Düsseldorf); Matsuoka, K. (Tokyo); Sruamsiri, R. (Tokyo/ Phitsanulok)

463 An Analysis of Transcobalamin II Gene Polymorphisms and Serum Levels of Homocysteine, Folate and Vitamin B12 in Chinese Patients with Crohn's Disease

Zheng, S.; Wu, C.; Yang, W.; Xia, X.; Lin, X.; Jiang, L.; Ding, R.; Jiang, Y. (Wenzhou)

472 Correlation of High-Resolution Manometric Findings with Symptoms of Dysphagia and Endoscopic Features in Adults with Eosinophilic Esophagitis

von Arnim, U.; Kandulski, A.; Weigt, J.; Malfertheiner, P. (Magdeburg)

Systematic Review and Meta-Analysis

478 Immunosuppressive Agents for the Treatment of Primary Sclerosing Cholangitis: A Systematic Review and Meta-Analysis

Peng, X.; Luo, X.; Hou, J.-Y.; Wu, S.-Y.; Li, L.-Z. (Guangzhou); Zheng, M.-H. (Wenzhou); Wang, L.Y. (Guangzhou)

No. 6

New Era of the Management of Liver Diseases and Liver Cancer: State-of-the-Art Progress in 2017

Editors: Kudo, M. (Osaka); Hyub Han, K. (Seoul)

Preface

493 New Era of the Management of Liver Diseases and Liver Cancer: State-of-the-Art Progress in 2017

Kudo, M. (Osaka-Sayama) 
Original Papers

498 Abdominal Ultrasound Findings of Tumor-Forming Hepatic Malignant Lymphoma

Kitahata, S.; Hiraoka, A. (Matsuyama); Kudo, M. (Osaka); Murakami, T.; Ochi, M.; Izumoto, H.; Ueki, H.; Kaneto, M.; Aibiki, T.; Okudaira, T.; Yamago, H.; Miyamoto, Y.; Iwasaki, R.; Tomida, H.; Mori, K.; Kishida, M.; Miyata, H.; Tsubouchi, E. (Matsuyama); Hirooka, M.; Koizumi, Y. (Toon) Ninomiya, T. (Matsuyama); Hiasa, Y. (Osaka); Michitaka, K. (Matsuyama)

506 Clinicopathological Study of Autoimmune Hepatitis Cases that Were Difficult to Differentiate from Drug-Induced Liver Injury

Tsutsui, A. (Kagawa); Harada, K. (Kanazawa); Tsuneyama, K. (Tokushima); Senoh, T.; Nagano, T.; Takaguchi, K.; Ando, M.; Nakamura, S.; Mizobuchi, K. (Kagawa); Kudo, M. (Osaka-Sayama)

515 Diagnosis of Fibrosis and Activity by a Combined Use of Strain and Shear Wave Imaging in Patients with Liver Disease Yada, N. (Osaka-Sayama); Tamaki, N. (Tokyo); Koizumi, Y. (Toon); Hirooka, M. (Tokyo); Nakashima, O. (Kurume); Hiasa, Y. (Tokyo); Izumi, N. (Toon); Kudo, M. (Osaka-Sayama)

521 Ability of Cytokeratin-18 Fragments and FIB-4 Index to Diagnose Overall and Mild Fibrosis Nonalcoholic Steatohepatitis in Japanese Nonalcoholic Fatty Liver Disease Patients Kobayashi, N.; Kumada, T.; Toyoda, H.; Tada, T.; Ito, T. (Ogaki); Kage, M. (Kurume); Okanoue, T. (Suita); Kudo, M. (Sayama)

531 Serum IFN- $\lambda 3$ Levels Correlate with Serum Hepatitis C Virus RNA Levels in Symptomatic Patients with Acute Hepatitis C Imoto, S.; Kim, S.R. (Kobe); Amano, K. (Kurume); Iio, E. (Nagoya); Yoon, S.; Hirohata, S. (Kakogawa); Yano, Y. (Kobe); Ishikawa, T. (Niigata); Katsushima, S.; Komeda, T. (Kyoto); Fukunaga, T. (Osaka); Chung, H. (Kobe); Kokuryu, H. (Kyoto); Horie, Y. (Gotsu); Hatae, T.; Fujinami, A.; Kim, S.K. (Kobe); Kudo, M. (Osaka-Sayama); Tanaka, Y. (Nagoya)

541 Comparison of Sofosbuvir Plus Ribavirin Treatment with Pegylated Interferon Plus Ribavirin Treatment for Chronic Hepatitis C Genotype 2

Seo, K.; Kim, S.K.; Kim, S.R.; Ohtani, A.; Kobayashi, M.; Kato, A.; Morimoto, E.; Saijo, Y.; Kim, K.I.; Imoto, S.; Kim, C.W.; Yano, Y. (Kobe); Kudo, M. (Osaka-Sayama); Hayashi, Y. (Kobe)

548 Hepatocarcinogenesis Is Associated with Serum Albumin Levels after Sustained Virological Responses with Interferon-Based Therapy in Patients with Hepatitis C Umehara, Y.; Hagiwara, S.; Nishida, N.; Sakurai, T.; Ida, H.; Minami, Y.; Takita, M.; Minami, T.; Chishina, H.; Ueshima, K.; Komeda, Y.; Arizumi, T.; Watanabe, T.; Kudo, M. (Osaka-Sayama)

556 Unique Characteristics Associated with Sustained Liver Damage in Chronic Hepatitis C Patients Treated with Direct Acting Antivirals

Kono, M.; Nishida, N.; Hagiwara, S.; Minami, T.; Chishina, H.; Arizumi, T. Minaga, K.; Kamata, K.; Komeda, Y.; Sakurai, T.; Takenaka, M.; Takita, M.; Yada, N.; Ida, H.; Minami, Y.; Ueshima, K.; Watanabe, T.; Kudo, M. (Osaka-Sayama)

565 Hepatocellular Carcinoma after Achievement of Sustained Viral Response with Daclatasvir and Asunaprevir in Patients with Chronic Hepatitis C Virus Infection

Ida, H.; Hagiwara, S.; Kono, M.; Minami, T.; Chishina, H.; Arizumi, T.; Takita, M.; Yada, N.; Minami, Y.; Ueshima, K.; Nishida, N.; Kudo, M. (Osaka-Sayama)
574 Non-Hypervascular Hypointense Hepatic Nodules during the Hepatobiliary Phase of Gadolinium-EthoxybenzylDiethylenetriamine Pentaacetic Acid-Enhanced MRI as a Risk Factor of Intrahepatic Distant Recurrence after Radiofrequency Ablation of Hepatocellular Carcinoma Iwamoto, T.; Imai, Y.; Igura, T.; Kogita, S.; Sawai, Y.; Fukuda, K.; Yamaguchi, Y.; Matsumoto, Y.; Nakahara, M.; Morimoto, O.; Ohashi, H.; Fujita, N. (Ikeda); Kudo, M. (Osaka-Sayama); Takehara, T. (Suita)

583 Impact of Tumor Factors on Survival in Patients with Hepatocellular Carcinoma Classified Based on Kinki Criteria Stage B2

Arizumi, T.; Minami, T.; Chishina, H.; Kono, M.; Takita, M.; Yada, N.; Hagiwara, S.; Minami, Y.; Ida, H.; Ueshima, K.; Kamata, K.; Minaga, K.; Komeda, Y.; Takenaka, M.; Sakurai, T.; Watanabe, T.; Nishida, N.; Kudo, M. (Osaka-Sayama)

589 Time to Transcatheter Arterial Chemoembolization Refractoriness in Patients with Hepatocellular Carcinoma in Kinki Criteria Stages B1 and B2

Arizumi, T.; Minami, T.; Chishina, H.; Kono, M.; Takita, M.; Yada, N.; Hagiwara, S.; Minami, Y.; Ida, H.; Ueshima, K.; Kamata, K.; Minaga, K.; Komeda, Y.; Takenaka, M.; Sakurai, T.; Watanabe, T.; Nishida, N.; Kudo, M. (Osaka-Sayama)

598 Hemodynamic Changes on Cone-Beam Computed Tomography during Balloon-Occluded Transcatheter Arterial Chemoembolization Using Miriplatin for Hepatocellular Carcinoma: A Preliminary Study

Ishikawa, T.; Imai, M.; Owaki, T.; Sato, H.; Nozawa, Y.; Sano, T.; Iwanaga, A. Seki, K.; Honma, T.; Yoshida, T. (Niigata); Kudo, M. (Osaka-Sayama)

602 Hepatic Function during Repeated TACE Procedures and Prognosis after Introducing Sorafenib in Patients with Unresectable Hepatocellular Carcinoma: Multicenter Analysis Hiraoka, A. (Matsuyama); Kumada, T. (Gifu); Kudo, M. (Osaka); Hirooka, M.; Koizumi, Y.; Hiasa, Y. (Toon); Tajiri, K. (Toyama); Toyoda, H.; Tada, T. (Gifu); Ochi, H.; Joko, K. (Matsuyama); Shimada, N. (Chiba); Deguchi, A. (Marugame); Ishikawa, T.; Imai, M. (Niigata); Tsuji, K. (Sapporo); Michitaka, K. (Matsuyama)

611 Sorafenib-Regorafenib Sequential Therapy in Advanced Hepatocellular Carcinoma: A Single-Institute Experience Ueshima, K.; Nishida, N.; Kudo, M. (Osaka-Sayama)

Review Article

618 Role of Immune Checkpoint Blockade in the Treatment for Human Hepatocellular Carcinoma Nishida, N.; Kudo, M. (Osaka-Sayama)

\section{Author Index}

624 Subject Index

625 Erratum 
